\title{
Lechner Ilona \\ AZ ERKÖLCS ERŐ fogalmi metaforára épülő laikus modellek a magyar és a német nyelvben
}

\begin{abstract}
The study discusses the role of the image scheme of FORCE DYNAMICS in the process of conceptualization of 'morality'. Having reviewed the academic literature, the linguistic manifestation of the conceptual metaphor MORALITY IS FORCE is examined in samples taken from Hungarian and German language corpora, then based on the results of the analysis the lay theories on morality based on the above-mentioned metaphor will be built. Comparing these, intercultural similarities, differences, and their causes are searched for.

Keywords: morality, force dynamics, metaphoric conceptualisation, lay theory
\end{abstract}

\section{Bevezetés}

Az erkölcs fogalma mélyen gyökerezik egy nép tudatában, mibenléte a hétköznapi emberek számára mégis nehezen megfogható. Több tudományág is foglalkozik a fogalom bizonyos aspektusaival. Filozófusok, morálpszichológusok, teológusok, jogászok igyekeznek a maguk szemszögéböl definiálni és összefüggésbe hozni saját fogalomrendszerükkel. Az erkölcs összefonódik többek között a társadalmi együttélés elfogadott normáival, ebböl kifolyólag meghatározza bizonyos viselkedési formáinkat, de szoros kapcsolatban áll a vallással, az írott törvényekkel, ezáltal a joggal is.

Az erkölcsiségről ritkán beszélünk nyíltan, erkölcskoncepciónk azonban nyelvünkben mégis tükröződik. A fogalom meghatározó jelentőséggel bír az élet bármely területén hozott döntéseinkben, nyelvi és nem nyelvi viselkedésünkben egyaránt. Erkölcsfelfogásunk tapasztalati alapja, a fizikai jóllét érzése potenciálisan univerzálisnak mondható, ugyanakkor a potenciálisan univerzális konceptualizáció a kontextus szociokulturális jellemzői miatt specifikus formákat ölthet. Jelen tanulmány AZ ERKÖLCS ERŐ fogalmi metaforára épülő laikus modellt hivatott bemutatni a magyar és a német kultúrkontextusban. A kutatás során a laikus modell következő értelmezését tartom szem előtt:

A világról alkotott tudásunk lehet mindennapos, laikus megfigyeléseken, tudáson alapuló, vagy szakértelemre épülő. Mindennapos tudásunkat laikus értelmezések, elméletek jellemzik, amelyek abban segítenek, hogy kiismerjük magunkat a világban. [...] A laikus elméletek gyakran szemben állnak a tudományos elméletekkel. (Kövecses \& Benczes 2010: 228) 
A megnevezett fogalmi metafora nyelvi manifesztációját vizsgálom meg a két nyelvben, majd az elemzési eredmények alapján felépítem a kétféle nyelvközösségben élö laikus elméleteket az erkölcsről. Ezeket összevetve interkulturális hasonlóságokat, különbségeket, valamint azok okait keresem.

\section{EIméleti keret, korábbi kutatások}

\subsection{A kognitív tudomány szerepe az 'erkölcs' megértésében}

Kutatásom elméleti keretét elsősorban az angol és magyar nyelven elérhető kognitív nyelvészeti szakirodalom szolgáltatja. Az elemzés a Lakoff (1996, 2002), illetve Lakoff \& Johnson (1999) által felépített erkölcskoncepcióra támaszkodik, amely ugyan az amerikai társadalom értelmezési folyamatát írja le, bizonyos részei azonban megközelítőleg univerzálisnak mondhatók, ebből kifolyólag más nyelvek vizsgálata során is szolgálhatnak hasznos megállapításokkal.

Lakoff \& Johnson (1999) meglátása szerint erkölcsfogalmaink metaforikus jellegéről való tudásunk meglehetősen eltérővé teszi moralitásfelfogásunkat. A kognitív tudomány olyan analitikus eszközöket nyújt számunkra, amelyek révén sokkal mélyebben érthetjük meg az erkölcsöt, mint ahogy az eddig elérhető volt számunkra. De mit jelent az, hogy mélyebb megértés, és ez hogyan befolyásolhatja gondolkodásunkat és életünket?

A legtöbb filozófus szkeptikus a fenti megállapítással kapcsolatban, véleményük szerint ugyanis az elme müködésére irányuló empirikus kutatások irrelevánsak az etika szempontjából. Kétkedésüket két dologgal magyarázzák: 1) Kitartanak amellett, hogy az emberek gondolkodásáról való tudásunk irreleváns abból a szempontból, hogy megmagyarázzuk, hogyan kellene gondolkodniuk. Nincsenek normatív magyarázatok, amelyeket le lehet vezetni az erkölcsfelfogásunkról rendelkezésre álló empirikus tudásanyagból. 2) Érvelésük szerint a fogalmi metaforák elemzése nem több mint hasznos eszköz arra, hogy tisztázzuk morális fogalmainkat, amelyek a metaforáktól függetlenül léteznek.

Vegyük szemügyre ezeket az ellenérveket. Az első ellenvetés, miszerint a morális kogníciónkról birtokolt empirikus tudásunknak nincsenek normatív implikációi, egy a tények és értékek közötti helytelen dichotómián alapszik. Flanagen (1992) bizonyította a morális pszichológia relevanciáját az erkölcselméletben, hiszen egyetlen moralitás sem lehet adekvát, ha az nem konzisztens azzal, amit a morális fejlődésről, érzelmekről, nemi különbségekről és önidentitásról tudunk. Johnson (1991) érvelése szerint a tények normatív korlátokat állítanak az emberi konceptualizáció és gondolkodás elé arra vonatkozóan, mit követelünk meg erkölcsileg magunktól és másoktól. Az empirikus kutatások relevánsak a különböző erkölcsi nézetek normatív értékelésében.

A második ellenérvvel kapcsolatban elmondhatjuk, hogy a metaforák nem azonosak az etikai fogalmakkal. Viszont erkölcsi metaforáink erősen befolyásolják, hogy miképpen gondolkodunk például az oktatásról vagy szociális fogalmakról. Ez azt jelenti, hogy az erkölcsiséggel kapcsolatos konceptuális rendszerünk szükségszerüen beleszól az oktatásügyi és szociális jellegü elmélkedésbe, valamint a politizálásba. Ezt viszont igyekeztem elkerülni a cikk írása folyamán, hiszen nem az volt a cél, hogy véleményt alkossunk az egyes nyelvközösségek politikai irányultságáról, szociális szférájáról stb.

Morális fogalmainknak nincs monolitikus, homogén, állandó rendszere. Például rendelkezünk különböző, nem állandó metaforikus struktúrákkal a jóllét fogalmáról, amelyeket müködtetünk morális gondolkodásunk során. Hogy mikor melyiket választjuk, pl. a JÓLÉT JÓLLÉT vagy 
a JÓLÉT EGÉSZSÉG, az a családmodellünk hierarchikus felépítésétől, céljainktól, érdeklődésünktől és az éppen aktuális kontextustól függ.

A kognitív nyelvészet két fontos fogódzót adott a morális megértéshez: elöször is egy mélyebb megértését annak, mi is az a morális gondolkodás, és honnan ered; másodszor a képességet, hogy bele tudjunk látni az apró részletekbe, hogy éppen melyik erkölcsi metaforát használtuk vagy használták mások, valamint hogy az a metafora milyen szerepet töltött be az erkölcsi következtetés levonása során.

A kutatás tervezésekor a kognitív nyelvészet egyik alaptételéből indultam ki, miszerint fogalmi rendszerünket lehetséges a nyelv vizsgálata által jellemezni. A gondolkodás és a nyelv között szoros kapcsolatot tételezhetünk fel: a gondolkodás a nyelvben manifesztálódik, ám a nyelv is hatással van magára a gondolkodás folyamatára (Kövecses \& Benczes 2010: 219).

\subsection{A metaforikus konceptualizációról}

Egy fogalomnak csak akkor van jelentése számunkra, csak akkor hordoz információt, ha azzal kapcsolatosan van bárminemü tapasztalatunk. A jelentés valójában azonos a konceptualizációval (Banćzerowski 2000: 243). Egy fogalom konceptualizációja, vagyis jelentésének megalkotása elménkben különböző kognitív folyamatok, pl. kategorizáció, fogalmi keretek ('frameek') létrehozása, metafora, metonímia, fogalmi integráció, alak-háttér elrendezés, képi séma stb., eredményeként történhet meg, amely folyamatok nagy része testi tapasztalatainkra vezethető vissza. A fogalmak között egy frame-en belül metonimikus, különböző frame-ek fogalmai között pedig metaforikus kapcsolatokat hozhatunk létre.

A metaforákat hagyományos értelemben a költői képek közé sorolják, és értelmezésüket az irodalmárok feladatának tartják. A metaforák funkciója eszerint valamilyen müvészi vagy retorikai hatás elérése. A kognitív nyelvelmélet követői szerint viszont a diszciplína fő feladata a természetes nyelv metaforikájának leírása, mivel a fogalmi metafora az egyik alapvető eszköze a konceptualizációs folyamatnak (Banćzerowski 1999).

A fogalmimetafora-elmélet ('conceptual metaphor theory', CMT) kognitív nyelvészeti alapját Lakoff \& Johnson (1980) Metaphors We Live By címü könyvében fejtette ki. Ez volt az a mü, amelyre a kognitív nyelvészek további kutatásaikat építették, kiegészítve és bővítve az elmélet atyáinak eredeti gondolatait. Kövecses (2005a) megfogalmazásában a fogalmi metafora kognitív nyelvészeti szempontból egy fogalmi tartomány (céltartomány, 'target domain') egy másik fogalmi tartomány (forrástartomány, 'source domain') terminusai által történő megértése. Megállapítja, hogy a „metaforákat a köznapi emberek is a legkisebb erőfeszítés nélkül használják (anélkül, hogy ennek tudatában lennének), ez nem csupán a különlegesen tehetséges emberek kiváltsága" (Kövecses, 2005a: 14). A fogalmi metaforák nyelvi megnyilvánulásai a metaforikus nyelvi kifejezések. Konceptualizációs rendszerünkben viszont a metaforák nemcsak nyelvi, hanem fogalmi szinten is léteznek. Lakoff \& Johnson (1980: 5) megfogalmazásában ,a fogalom metaforikusan strukturált, a tevékenység is metaforikusan strukturált, és ebből következik, hogy a nyelv is metaforikusan strukturált". ${ }^{1}$ Különböző fogalmi tartományok ('domains') között átjárhatóság áll fenn, ami azt jelenti, hogy az egyiket interpretálhatjuk a másikban lévő tudás által. Ezt a folyamatot nevezzük valójában metaforikus gondolkodásnak (Kövecses 2005b).

1 „The concept is metaphorically structured, the activity is metaphorically structured, and, consequently, the language is metaphorically structured." (Lakoff \& Johnson 1980: 5) 
A metafora Banćzerowski (2000) megfogalmazásában

[...] olyan eszköze az embernek, amely lehetővé teszi bizonyos absztrakt cselekvések és tartalmuk konkrét módon történő kifejezését. A metaforának köszönhetően az ember jobban felfogja azt, amit képtelen teljes egészében megérteni, nevezetesen az érzelmeket, az értékeket, a pszichikai folyamatokat. (Banćzerowski 2000: 322)

A fogalmi metaforákat tehát a már említett két tartomány alkotja, a forrás- illetve a céltartomány, amelyek között ún. leképezések ('mappings') jönnek létre. A CMT szerint a metaforikus leképezések rendszerében az absztrakt fogalom (céltartomány) bizonyos elemei kivetítődnek a konkrétabb fogalom (forrástartomány) megfelelő elemeire, amely ezáltal hozzáférést biztosít az elvont fogalomhoz, így segítve annak megértését. Ez a folyamat többnyire a konkréttól az elvont felé haladva történik, ezt nevezzük az egyirányúság elvének (Kövecses 2005a: 22).

A forrástartomány nem minden elemét vetítjük rá a céltartományra, hanem az éppen aktuális kontextusnak megfelelően válogatunk közülük. A forrástartománynak számtalan különböző aspektusa van, amelyek között szelektálunk, és a kiválasztottakat hozzárendeljük a céltartomány megfelelö aspektusaihoz.

Egy forrástartomány nem csak egy céltartományhoz biztosíthat mentális hozzáférést. Az ERÖ forrástartományt például felhasználhatjuk nemcsak az ERKÖLCS, hanem más elvont fogalmak megértéséhez is. Ezt nevezzük a forrástartomány hatókörének ('scope of source'), amely tehát nem más, mint a céltartományok összessége, amelyek egyazon forrástartomány által érhetők el mentálisan. Egy céltartományt hasonlóképpen nem csak egy forrástartomány elemei által érthetünk meg. A forrástartományok összességét, amelyek egy céltartomány konceptualizálásában részt vesznek, a céltartomány kiterjedésének ('range of target') nevezzük.

A forrástartományokról rendkívül gazdag tudással rendelkezünk, mivel azok valójában a körülöttünk lévő konkrét dolgok, általunk megtapasztalt események. Ennek a többlettudásnak köszönhetően vagyunk képesek a tudáselemek közül néha olyant is rávetíteni a céltartományra, amely túlmutat az alapvető leképezéseken. Ezeket metaforikus következményeknek, implikációknak ('metaphorical entailments/inferences') nevezzük (Kövecses \& Benczes 2010: 229).

A leképezések és metaforikus következmények között sokszor csak szubjektíven tudunk különbséget tenni. Fontos azonban megjegyezni, hogy alapvető mentális képességünk betartani az ún. invariancia elvet, amely szerint: „Figyelembe véve a metaforikus leképezésekben részt vevő aspektus(oka)t, annyi tudást képezzünk át a forrástartományból a céltartományba, amennyi még koherens a céltartomány képiséma-tulajdonságaival!” (Kövecses 2005a: 114). Ezáltal a forrástartomány megőrzi lényegi szerkezetét, invariáns marad.

A kognitív nyelvészet szerint a fogalmi metaforában részt vevő két fogalom között nem feltétlenül van valós hasonlóság. A diszciplína képviselői amellett érvelnek, hogy a fogalmi metaforák alapja lehet a forrás- és céltartomány közötti valós vagy vélt hasonlóság, analóg kapcsolat, valamint a testi tapasztalatok korrelációja (Kövecses 2015). E felfogás szerint a fogalmi metafora alapulhat valós vagy érzékelt hasonlóságon vagy korreláción, amelyek tapasztalati alapként ('experiential basis', Lakoff \& Johnson 1980) motiválják azt. A motivációnak az alábbi fajtáit különböztetjük meg:

- tapasztalatok közötti összefüggések;

- érzékelt szerkezeti hasonlóság;

- ontológiai metaforákon alapuló érzékelt szerkezeti hasonlóság;

- a forrástartomány mint a céltartomány eredete (Kövecses 2010a: 79-86). 
Kutatásom során a metaforikus nyelvi kifejezések elemzését a felvázolt fogalmimetafora-elméletre alapozom.

\subsection{A metaforakutatás szintjei}

A metaforakutatásnak három szintjét különböztetjük meg attól függően, hogy konkrétan mi áll a kutató érdeklődésének középpontjában. Kövecses (2005a: 237-243) szerint a három szint a következö.

Az egyén fölötti (szupraindividuális) szint: ezen a szinten a metaforákat kontextus nélkül, a beszélőtől elvonatkoztatva vizsgálják a kognitív nyelvészek, például szótárak alapján.

Az egyén szintje (individuális): a beszélők fogalmi rendszerében létező metaforákkal foglalkozik. Elsősorban a pszicholingvisták és a kognitív pszichológusok kutatási területe.

Az egyén alatti (szubindividuális) szint: a kutatók (Ekman, Levenson \& Friesen 1983; Pfaff, Gibbs \& Johnson 1997) olyan testi és érzékelési tapasztalatokat vesznek szemügyre, amelyek a fogalmi metaforák alapjául szolgálhatnak, motiválják azok létrejöttét.

A kognitív nyelvészeti kutatásokat az elméleti nyelvészek többnyire az egyén fölötti szinten végzik. Elemzéseik során azonosítják a különböző nyelvekben fellelhető konvencionális fogalmi metaforákat és azok rendszerét. Ezeket a nyelvészeti kutatásokat a „felülről lefelé” ('top down', Stefanowitch 2006) vizsgálati módszerrel végzik, amely szótári példák alapján feltételezi bizonyos fogalmi metaforák létezését.

A szövegkörnyezet ignorálása és az intuitív példák vizsgálata miatt számos kritika érte a kognitív metaforaelméletet (Alverson 1994; Dobrovolskij \& Piirainen 2005; Clausner \& Croft 1997; Rakova 2002, Stefanowitch 2006; Steen 1999; Semino 2005, Zinken 2007). Ezekre reagálva véli fontosnak Kövecses (2006a) világosan elkülöníteni a fent említett szinteket, illetve a különböző szinteken történő kutatások célját. Az egyén szintjén ugyanis konkrét metaforikus nyelvi kifejezések beazonosítása történik. Kutatóként tehát a vizsgálat során „alulról felfelé" ('bottom up') építkezünk oly módon, hogy

nagyszámú kifejezést (pl. teljes korpuszokat) vizsgálunk meg, a metaforikus kifejezéseket szisztematikusan, egy jól meghatározott protokoll segítségével azonosítjuk be, majd megnézzük, hogyan viselkednek a metaforikus elemek a konkrét szituációban (szemantikai, strukturális, pragmatikai, esztétikai stb. szempontokból), és esetleg egy többlépcsős folyamat végén jutunk el fogalmi metaforák posztulálásához (ld. például Steen 1999). Az ilyen jellegủ vizsgálatokban tehát figyelmünk középpontjában a nyelv és a nyelvi metaforák, valamint ezek viselkedése áll. (Kövecses 2006a: 88)

E két vizsgálati módszer kiegészíti egymást, amennyiben célul tüztük ki egy absztrakt fogalom minél pontosabb leírását. A kvantitatív vizsgálatokat intuitív kvalitatív elemzéssel kell kiegészíteni. Ezt az elvet törekszem követni az elemzés során. ${ }^{2}$

\subsection{A metaforák kulturális különbségei}

A metaforák variálódásának okaként a kognitív nyelvészek (Lakoff \& Turner 1989; Kövecses 2005b, 2010b, 2012, 2015; Sharifian 2006, 2008) elsősorban a kontextust nevezik meg, amelynek kettős szerepe van a jelentésalkotási folyamat során. Egyrészt variálódásra ad lehetőséget, másrészt viszont korlátozó funkciója van. Kövecses (2005b) bevezeti a koherencia kényszere

\footnotetext{
2 Az elemzés menetéröl lásd a 4.2 alpontot.
} 
('pressure of coherence') kifejezést, amely kettős kényszerüséget jelent az interakciókban résztvevőkre nézve: jelentésalkotási folyamatunk során összhangban kell lennünk a) saját testünkkel, b) illetve a kontextussal is.

A metaforák között több síkon megfigyelhetünk különbségeket. Beszélhetünk

- kultúrák közötti (interkulturális),

- kultúrán belüli (intrakulturális),

- egyéni,

- történelmi,

- és fejlődési/életkori eltérésekről.

Az eltérések különböző módon jelentkezhetnek mindegyik dimenzióban. Egyes fogalmi metaforákban eltérő lehet a forrás- és céltartomány, valamint a közöttük lévő kapcsolat, a tapasztalati alap, a metaforikus nyelvi kifejezések, a leképezések rendszere, metaforikus következmények, nem nyelvi realizációk, blendek és kulturális modellek. Ezek lehetnek a variálódás okai és elszenvedői is.

A variálódás okaként két faktort nevezhetünk meg: a különböző tapasztalatot és a különböző kognitív stílust.

Előbbi magában foglalja a kontextustudatosságot, a különböző emlékezetet és érdeklődést. A kontextustudatosságot az határozza meg, hogy mennyire vagyunk tisztában a fizikai, szociális, kulturális, valamint a kommunikációs szituáció közvetlen tényezőivel. A különböző emlékezet magában foglalja mindazokat a tárgyakról, eseményekröl birtokolt emlékképeket, amelyeket egy közösség tagjai vagy maga az egyén megoszt. Az eltérő érdeklődés arra az általános attitüdre utal, ahogyan csoportok vagy egyének cselekednek vagy hajlamosak cselekedni a világban. A tapasztalati alap kihat globális és lokális szinten. A globális kontextus az az általános tudás, amelyet egy közösség tagjai birtokolnak, és amely hatással van minden közösségi tag metaforahasználatára. A lokális kontextus ezzel szemben az a specifikus tudás, amely egyes szituációkban bizonyos személyekre vonatkozik.

\section{Az ERŐDINAMIKA képi séma}

Elvont fogalmak konceptualizációja során fontos szerepük van a képi sémáknak (TARTÁLY, RÉSZ-EGÉSZ, OKOZÁS stb). A képi sémák „olyan sematikus, absztrakt struktúrák, amelyeket annak alapján jellemezhetünk, hogy milyen fizikai tapasztalatokra vezethetők vissza, milyen elemekből állnak, milyen alapvető logikát (struktúrát) követnek, illetve milyen fogalmi metafora épül rájuk" (Kövecses \& Benczes 2010: 227). Az ERKÖLCS fogalom esetében kiemelt jelentőséggel bír az erőkre és ellenerőkre alapozott képi séma (Talmy 1988). Az ERÖDINAMIKA müködésében a következő elemek vesznek részt (ld. 1. táblázat):

\begin{tabular}{|l|l|l|l|}
\hline Erőkifejtő entitások & Az erő lényegi tulajdonságai & Erőegyensúly & $\begin{array}{l}\text { Lehetséges } \\
\text { következmények }\end{array}$ \\
\hline erő (agonista) & hatást kifejteni & erősebb entitás & cselekvés \\
\hline ellenerő & nyugalomban maradni & gyengébb entitás & nyugalom \\
\hline
\end{tabular}

1. táblázat. Az erődinamika legföbb elemei események jellemzéséhez (Kövecses \& Benczes 2010: 137) 
Az ERÖDINAMIKA alapján az erkölcsös személyre, aki ugyanolyan akar maradni, mint amilyen addig volt, egy külső (fizikai) erő hat, amely megpróbál valamilyen hatást elérni. Eszerint tehát két erö áll szemben egymással: egy gonosz erő és az ego. Az ego valójában az erkölcsös személy, aki küzd a rá ható külső vagy belső erővel. Ha az emberi testet tartályként értelmezzük, amelyre különböző erők hatnak, akkor a konceptualizációs folyamatban ez alapján a KINT/BENT, valamint a TARTÁLY sémák is részt vesznek. A külső erő esetében a testen kívülről jön a támadás, míg a belső erő esetében a testen belül zajlik a harc.

Az általános erődinamika müködését az erkölcsre vonatkoztatva a következőképp lehet táblázatban összefoglalni (ld. 2. táblázat).

\section{Forrástartomány: KÉT (KÜLÖNBÖZÖ) FIZIKAI ERÖ}

Céltartomány: ERKÖLCS

\begin{tabular}{|l|c|c|c|}
\hline Megfelelés & $\begin{array}{c}\text { Agonista lényegi } \\
\text { tulajdonságai }\end{array}$ & $\begin{array}{c}\text { Antagonista lényegi } \\
\text { tulajdonságai }\end{array}$ & Következmények \\
\hline Forrástartomány & $\begin{array}{c}\text { Fizikai tárgy } \\
\text { ugyanolyannak } \\
\text { megmaradni, } \\
\text { mint volt }\end{array}$ & $\begin{array}{c}\text { Fizikai erö } \\
\text { valamilyen hatás } \\
\text { előidézése a Fizikai } \\
\text { tárgyban }\end{array}$ & Nincs hatás \\
\hline Céltartomány & $\begin{array}{c}\text { Ego } \\
\text { Ellenállni } \\
\text { a Kísértésnek } \\
\text { (erkölcsösnek } \\
\text { maradni) }\end{array}$ & $\begin{array}{c}\text { Kísértés } \\
\text { Célja, hogy } \\
\text { az Ego elveszítse } \\
\text { ellenállását }- \text { tehát } \\
\text { hogy erkölcstelenné } \\
\text { váljon }\end{array}$ & $\begin{array}{c}\text { Az Ego ellenáll } \\
\text { árértésnek }- \text { tehát }\end{array}$ \\
\hline
\end{tabular}

2. táblázat: AZ ERKÖLCS ERŐ ERŐDINAMIKA-alapú értelmezése (Kövecses \& Benczes 2010: 141)

Az erkölcsös cselekedet lényegi feltétele az akaraterő. Erkölcsi erő nélkül nem lennénk képesek alakítani a morális tudatunkat és megvalósítani a morális értékeket, tehát a morális rendszerben központi szerepet játszik ez a komplex metafora, amely szerint létezik az erő, amellyel legyőzzük a gonoszt, s ez segít fenntartani az egyenes és kiegyensúlyozott magatartást. Tehát a gonosz folyamatos leküzdése révén válunk gerincessé, erkölcsössé (Szelid 2007).

Abból az alapvető testi tapasztalatból, hogy jobb kiegyensúlyozottnak és kiegyenesedettnek lenni, következik az a metafora, hogy AZ ERKÖLCSÖS CSELEKEDET FENT VAN, míg AZ ERKÖLCSTELEN LENT VAN. Ha rosszat teszünk, akkor elmozdulunk az erkölcsöstöl (amely fent van) az erkölcstelen (amely lent van) felé, vagyis AZ ERKÖLCSTELEN CSELEKEDET ESÉS. Mivel ahhoz, hogy fent legyünk vagy maradjunk valahol, egyensúlyra van szükségünk, az egyik metaforikus következmény, hogy JÓNAK LENNI EGYENSÚLYBAN LENNI.

A komplex metafora másik aspektusa foglalkozik azzal, hogy kontroll alatt tartsuk magunkat és a gonoszt. A gonosz (külső vagy belső) erö, amely okozhatja, hogy leessünk vagy elveszítsük a kontrollt, vagyis erkölcstelen dolgot cselekedjünk. Ebből következik A GONOSZ BELSŐ VAGY KÜLSŐ ERÖ metafora. A külső erö lehet pl. egy személy, belső lehet a testi szenvedély, vágy. Közöttük metonimikus kapcsolat figyelhető meg: valamilyen külső dolog vagy egy személy 
kelt bennünk belső vágyat. Ahhoz, hogy fent maradjunk, elég erősnek kell lennünk, hogy ellenálljunk a gonosznak. Az ember azonban nem születik erősnek, a morális erőt fel kell építeni. Megtehetjük ezt önfegyelemmel és önmegtagadással. Kétfajta morális erő létezik attól függően, hogy belső vagy külső gonosszal állunk szemben. Bátorság kell a külső gonosz legyőzéséhez, és akaraterőre van szükség a belső szenvedély elnyomására. Az önfegyelem ellentéte az önkényeztetés, amely csak akkor nyer értelmet, ha elfogadjuk AZ ERKÖLCS ERÖ metafora létezését. Az önkényeztetés ebben a metaforában vétek, hiszen a takarékosság és az önmegtagadás számítanak erénynek. Az ERKÖLCS ERÖ metafora értelmezésén keresztül a hét főbűn belső gonosznak számít, amelyeket le kell győzni, ellentétüket pedig erényként értékeljük.

A Lakoff (1996) által kidolgozott ERKÖLCS ERŐ fogalmi metafora a következő elemekből áll:

A JÓ CSELEKEDET FENT VAN: FENT LENNI $\rightarrow$ JÓNAK LENNI (az erkölcsi tudat magasabb rendü); ${ }^{3}$ A ROSSZ CSELEKEDET LENT VAN: LENT LENNI $\rightarrow$ ROSSZNAK LENNI (lejárató kampány);

AZ ERKÖLCSTELENNÉ VÁLÁS ZUHANÁS: ESNI $\rightarrow$ ROSSZAT CSELEKEDNI (bünbe esik, lezüllik);

A KÍSÉRTÉS ERŐ: DESTABILIZÁLÓ ERÖ $\rightarrow$ KÜLSŐ VAGY BELSŐ GONOSZ (elnyomja vágyait);

AZ ERKÖLCSÖSSÉG ERÖ: ERŐ (ELLENÁLLNI) $\rightarrow$ MORÁLIS ERÉNY (ellenállt a kisértésnek, csábitásnak).

A metafora következményei:

Jónak maradni a gonosszal szemben, morálisan erősnek kell lenni.

Önfegyelem és önmegtagadás által válhatunk morálisan erőssé.

Aki morálisan gyenge, nem tud ellenállni a gonosznak, és elköveti a rosszat.

A morális gyengeség az immoralitás egy formája.

Az önkontroll, önfegyelem hiánya és az önkényeztetés az immoralitás formája.

\section{$4 \quad$ A kutatás módszertana}

Egy fogalom prototipikus kulturális modellje lényegében az a laikus modell, amely az egy kultúrához tartozó emberek mindennapi nyelvében tükröződő tudására épül (Kövecses 2006b: 369).

A tanulmány súlyponti része a gyüjtött anyag elemzése, amelyhez a korpusznyelvészet módszertanát használtam fel, tehát az „,alulról felfelé” elemzési irányt követtem. Az empirikus kutatás két nagyobb részre oszlik. Elsőként magyar és német adatbázisokból összeállítottam a nyelvi korpuszt. Ehhez az erkölcs és Moral keresőszavakat használtam egész mondatos konkordanciával. A magyar nyelvre vonatkozóan a Magyar Nemzeti Szövegtár újabb, kibővített változatának adatbázisát használtam. A német nyelvü korpusz összeállítása céljából a Német Nyelv Digitális Szótárában (Digitales Wörterbuch der Deutschen Sprache) végeztem keresést, amelynek előnye, hogy a beállítások által különböző korokban vizsgálhatjuk meg a fogalom elöfordulását, így a két nyelvben közel azonos időszakból (2002-2018) származó nyelvi példákkal dolgoztam.

\footnotetext{
3 A nyelvi példák a magyar nyelvủ korpuszból származnak.
} 


\subsection{A vizsgálati korpusz}

Kutatásomat két korpuszon végeztem, amelyek egyenként 3000 nyelvi megnyilatkozást tartalmaznak.

A magyar nyelvű mintát a Magyar Tudományos Akadémia Nyelvtudományi Intézete által müködtetett Magyar Nemzeti Szövegtárból ${ }^{4}$ (továbbiakban MNSZ2) állítottam össze, amely 187,6 millió szövegszót tartalmaz öt régióból: Magyarországról, Erdélyből, a Felvidékről, a Vajdaságból és a Kárpátaljáról. A regionális különbségekre részletesen nem térek ki, mivel a részkorpuszokban nagyságrendileg eltérö találatot kaptam a kulcsszavas keresés során. Így azok nem nyújtanak alapot egy reprezentatív összehasonlításhoz. Ennek ellenére a vizsgált korpusz jellegéből következően átfogó képet kapunk a magyarok erkölcsszemléletéröl. Az MNSZ2 öt stílusrétegből (sajtó, szépirodalom, tudományos, hivatalos, személyes) tartalmaz szövegeket 2002-től kezdődően. A keresés során a szépirodalom stílusrétegét nem vettem figyelembe, mivel az irodalmi szövegekben elöforduló specifikus metaforákat ki akartam zárni az elemzésből. Ennek oka, hogy a tanulmány célja nem a nyelvi kreativitás bemutatása, hanem inkább a hétköznapi nyelvhasználatban előforduló metaforikus nyelvi kifejezések elemzése. Ilyen feltételek mellett az erkölcs keresőszót használva szótöves formában összesen 10440 találatot kaptam, amelyek közül véletlenszerü választással 3000 nyelvi kifejezést tartalmazó mintát állítottam össze. Egész mondatos lekérdezéssel dolgoztam annak érdekében, hogy a metaforikusnak ítélt nyelvi kifejezés kontextusát minél pontosabban meg tudjam határozni. Az ismétlödéseket leszámítva 2657 nyelvi megnyilvánulásból 2216-ot ítéltem metaforikusnak az elemzési kritériumok alapján.

A német minta összeállításához a Digitales Wörterbuch der deutschen Sprache ${ }^{5}$ (A német nyelv digitális szótára, továbbiakban DWDS) nemzeti korpuszt használtam fel. Ennek egy részében, a referencia- és újságkorpuszban végeztem keresést, amely több részkorpuszt egyesít. Ennek előnye, hogy körülbelül ugyanazokat a stílusrétegeket fedi le, mint az MNSZ2, illetve az is beállítható, hogy milyen időintervallumból származzanak a szövegek. A DWDS megnevezett részkorpusza 1473-2018 közötti időszakra kiterjedően összesen 5,9 milliárd szövegszót tartalmaz. A reprezentatív összehasonlítás érdekében azonban a 2000-2018 közötti időszakban végeztem keresést a Moral keresőszóval. Így 8884 találatot kaptam, amelyekből véletlenszerü lekérdezéssel a magyarhoz hasonlóan 3000 találatot tartalmazó vizsgálati mintát állítottam össze. Miután kizártam az ismétlődéseket, 2948 nyelvi megnyilvánulás maradt, amelyek közül 2320-at ítéltem metaforikusnak.

A vizsgálati mintákat a 3. táblázat foglalja össze.

\begin{tabular}{|c|c|c|c|c|c|}
\hline Korpusz & Keresőszó & $\begin{array}{c}\text { Találatok } \\
\text { száma } \\
\text { összesen }\end{array}$ & $\begin{array}{c}\text { Vizsgált } \\
\text { minta }\end{array}$ & $\begin{array}{c}\text { Vizsgált minta } \\
\text { ismétlődések } \\
\text { nélkül }\end{array}$ & $\begin{array}{c}\text { Metaforikus } \\
\text { nyelvi kifejezések }\end{array}$ \\
\hline MNSZ & 'erkölcs' & 10440 & 3000 & 2657 & 2216 \\
\hline DWDS & 'Moral' & 8884 & 3000 & 2948 & 2320 \\
\hline
\end{tabular}

3. táblázat. Vizsgálati korpusz

http://mnsz.nytud.hu/ (letöltve 2017. 11.25)

https://www.dwds.de/ (letöltve 2017. 12. 16) 


\subsection{Az elemzés menete}

Az elemzést a következő lépésekben végeztem el:

A) A keresés kulcsszavai az 'erkölcs', illetve a 'Moral', amelyek az ERKÖLCS kategória központi tagjának tekinthetők. A kiválasztott alkorpuszokban ezen kulcsszavakra keresve néztem meg 3000 véletlenszerü elöfordulást és gyüjtöttem nyelvi kifejezéseket.

B) A Pragglejaz csoport (2007) által kidolgozott (MIP), majd Steen és társai (2010) által továbbfejlesztett metaforaazonosítási módszert (MIPVU) követtem annak megállapításában, hogy mely nyelvi kifejezések metaforikusak. Ezt a többlépcsős eljárást alkalmazva kizárható a szubjektivitás, a kutató nyelvi intuíciója (Kövecses 2010a: 5):

1) Az egész szöveg (teljes példamondatok) elolvasása az általános jelentés megállapítása céljából.

2) A szöveg (példamondat) nyelvi egységekre, szavakra bontása.

3) i) A szavak jelentésének vizsgálata, van-e többjelentésű szó közöttük. ii) Az elsődleges jelentés megállapítása a szöveg összes szava esetében.

4) A kontextus figyelembevétele: ha az elsődleges jelentés és a szövegben megfigyelhető jelentés eltér, a metafora tényének megállapítása.

C) A figuratív nyelvi kifejezéseket fogalmi metaforák szerint csoportosítottam, megvizsgáltam az azonosított közvetítő entitásokat és forrástartományokat.

D) Az azonosított fogalmi metaforákat lehetőség szerint fö- és alcsoportokba rendeztem. $\mathrm{Az}$ elemzés során az ontológiai metaforák felöl haladtam az egyre specifikusabb szerkezeti metaforák felé. Azokat a fogalmi metaforákat, amelyeknek mindössze egy metaforikus nyelvi megnyílvánulását találtam (1 típus ['type'] szintjén fordult elö) a korpuszban, kizártam az elemzésböl.

E) Azonosítottam a fogalmi metaforákat alkotó leképezéseket (mappings) és a metaforikus implikációkat (metaphorical entailments). Ezt fontos lépésnek ítéltem, hiszen minél több leképezés vesz részt a jelentésalkotásban és manifesztálódik a nyelvben, annál kidolgozottabbnak tekinthetö a fogalmi metafora.

F) Megállapítottam az azonosított fogalmi metaforák gyakoriságát (frequency) a vizsgált kontextusokban.

Jelen tanulmány a felvázolt átfogóbb elemzés részeredményét mutatja be, konkrétan $\mathrm{AZ}$ ERKÖLCS ERÖ metaforára koncentrál.

\section{Kutatási eredmények}

Az 'erkölcs' fogalmát a magyar és a német nyelvben az általam választott, nyelvi korpuszon végzett, alulról felfelé építkező módszerrel mindezidáig nem tárták fel, tehát az ERŐDINAMIKA képi séma nyelvi realizálódását sem vizsgálták meg konkrét nyelvi példákon az említett két nyelvben. A jelen tanulmányban bemutatott lakoffi és johnsoni amerikai erkölcskoncepció idevágó része, tehát AZ ERKÖLCS ERŐ metafora leírása egy felülröl lefelé történő vizsgálat eredménye. Felmerül azonban a kérdés, hogy az általuk megállapított fogalmi metaforák jelen vannak-e a magyar és a német nyelvben is. 


\subsection{A magyar korpusz elemzésének összefoglalása}

A Lakoff (1996) által kidolgozott AZ ERKÖLCS ERŐ fogalmi metafora a magyar nyelvben a következőképp manifesztálódik:

A JÓ CSELEKEDET FENT VAN

(1) Ha feltesszük, hogy az erkölcsi tudat magasabb rendü (több), mint a nem erkölcsi (pl. állati) tudat.

A ROSSZ CSELEKEDET LENT VAN

(2) De még mindig nem értem, hogy Horn miként züllesztette le az < erkölcsöt > és a gazdaságot?

\section{AZ ERKÖLCSTELENNÉ VÁLÁS ZUHANÁS}

(3) Legyetek < erkölcs > nélküli emberbábok, akik aztán mind mélyebbre zuhannak a sátán által nyújtott örömök hajszolása közepette!

A KÍSÉRTÉS ERŐ

(4) Még álmunkban is csak ,azon” jár az eszünk, vagyis pontosabban ekkor leginkább, mert nappali tudatunkkal még csak-csak el tudjuk nyomni sürgetö szexuális késztetéseinket, az éjszakai tudat azonban nem ismeri a nappali < erkölcs > pirulását.

\section{AZ ERKÖLCSÖSSÉG ERÖ}

(5) Nem az < erkölcseim >, hanem a józan eszem tiltakozik az ellen, hogy [...]

A magyar nyelvü korpuszban a komplex metafora mindegyik elemére találunk metaforikus nyelvi példákat, amelyeket további elemzésnek vetünk alá. A (4) példabeli kifejezés egyrészt metonímián alapul, másrészt névszói megszemélyesítés is található benne. Az erkölcs pirulása kifejezésben A HATÁS AZ OK HELYETT metonímia manifesztálódik. A pirulás oka a szégyen, amelyet amiatt érzünk, hogy éjjel nem vagyunk képesek elnyomni a vágyainkat, és engedünk a kísértésnek. Az (5) példamondatban pedig igei megszemélyesítés van az ERŐDINAMIKA mellett.

AZ ERKÖLCS ERŐ fogalmi metafora szorosan összekapcsolódik a Lakoff (1996) által felépített családmodell-elmélettel. A SZIGORÚ APA családmodell egyik alappillére, hogy az apa szigorával és tekintélyével a gyerekét ezekre az erényekre neveli annak érdekében, hogy ne legyen morálisan gyenge.

A belső erő vagy az ego megjelenhet MORÁLIS KORLÁTként is, ami a vázolt ERŐDINAMIKA müködése révén legyőzi a gonosz erőt, ezáltal megakadályozza a cselekvést.

(6) < erkölcse > akadályozta abban, hogy...

Az ERŐDINAMIKA képi séma központi szerepet játszik a HARC idealizált kognitív modellben (azaz IKM-ben), amelyröl részletes tudással rendelkezünk. Laikus ismereteink szerint a HARC IKM a következő elemekből épül fel: A SZEMBENÁLLÓ FELEK (ELLENFELEK), A HARC ESZKÖZE, A HARC SZÍNTERE, A HARC FOLYAMATA, A HARC EREDMÉNYE/VÉGKIMENETELE (GYÖZELEM/VERESÉG).

Az 'erkölcs' fogalomra vonatkoztatva az ERÖDINAMIKA alapján a szemben álló felek a külső/belső erő és az ego, a harc eszköze az akaraterő/önmegtagadás, a harc folyamata az ego küzdelme a külső/belső erővel, a harc végkimeneteleként az ego erkölcsös marad vagy erkölcstelenné válik. 
A vizsgált korpusz adatait elemezve a következő metaforák nyelvi manifesztációit találtam: ERKÖLCSÖSNEK LENNI HARC

(7) De a történelemben egyre jobban izgatja a küzdelem az emberiségért, a helyes életszabályokért, < erkölcsért >, igazságos jogért.

\section{ERKÖLCSÖSNEK MARADNI GYÖZNI A HARCBAN}

(8) Az 56-osok nemzedékének olyan képviselöjét ismertem meg benne, aki érti és értékeli a magyar nemzet legjobbjainak történelmi harcát a szabadság, az emberi méltóság és az < erkölcs > gyözelméért.

ERKÖLCSTELENNÉ VÁLNI VESZÍTENI A HARCBAN

(9) Az utóbbi esetben azt, hogy a jog gyözedelmeskedett, az elsöben azt, hogy az < erkölcs > kapott egy nagy pofont.

A (7), (8), (9)-es példamondatok között az a különbség, hogy az előzőben a harc folyamatára fókuszálunk, míg a két utóbbian a harc végkimenetelére. A (9)-es példában az egymással szembenálló felek, a jog és az erkölcs is kifejezésre jutnak.

AZ ERKÖLCS ERÖ metafora egyik metaforikus következménye, hogy a JÓNAK (ERKÖLCSÖSNEK) LENNI megfelelője EGYENSÚLYBAN/EGYENESNEK LENNI.

(10) [...] a szenátor integráns, szabad és független személyiség, „kisebbség” képviselője, akinek < erkölcseit > - mint például az ifjabb Bushét - semmiféle kilengés nem terheli.

(11) A Horn-kormány a jövö esélyeit teszi tönkre a családellenes, iskola- és ifjúságellenes politikával, a túladóztatás az amúgy is megrendült < erkölcsöket > zülleszti le teljesen, és visszafogja a munkahelyteremtö vállalkozásokat.

(12) És nem is csak az egyén számára, az < erkölcsében >, tartásában megroggyant népek számára is.

A kilengés egyértelmüen a testi egyensúly megingását jelenti a (10)-es példamondatban. A (11)-es nyelvi példát úgy értelmezhetjük, hogy amennyiben az ERKÖLCS mint SZEMÉLY megrendülhet vagy meginoghat, elveszítheti önkontrollját, és lezüllik, vagyis erkölcstelenné válik, ami AZ ERKÖLCSTELEN LENT VAN fogalmi metafora nyelvi manifesztációja. A (12)-es mondatban megjelenő metaforikus nyelvi kifejezés értelmezésében ugyancsak szerepet játszik az erődinamika. Az erkölcsös egyén a rá ható erő eredményeként megroggyant, ami azt jelenti, hogy elveszítette egyenes tartását. Jelen esetben az ERKÖLCSÖS annyi, mint EGYENES, fogalmi fókuszában az erős fizikai tartás áll.

A számadatok alapján AZ ERKÖLCS ERŐ metafora nyelvi manifesztációi az összes metaforikus nyelvi kifejezés mindössze 6,85\%-át teszik ki. Az ontológiai metaforán belül AZ ERKÖLCSÖSSÉG ERÖ, valamint a FENT-LENT metaforikája szinte ugyanolyan hangsúlyt kap. 


\begin{tabular}{|l|l|}
\hline AZ ERKÖLCS ERÖ & Gyakoriság $(\%)$ \\
\hline Szerkezeti metafora & 32,77 \\
\hline AZ ERKÖLCSÖSSÉG ERÖ & 21,0 \\
\hline A JÓ CSELEKEDET FENT VAN & 14,29 \\
\hline ERKÖLCSÖSNEK MARADNI GYÖZNI A HARCBAN & 12,60 \\
\hline A ROSSZ CSELEKEDET LENT VAN & 5,88 \\
\hline $\begin{array}{l}\text { JÓNAK (ERKÖLCSÖSNEK) LENNI EGYENSÚLYBAN/EGYENESNEK } \\
\text { LENNI }\end{array}$ & 5,04 \\
\hline A KÍSÉRTÉS ERÖ & 4,2 \\
\hline ERKÖLCSTELENNÉ VÁLNI VESZÍTENI A HARCBAN & 4,2 \\
\hline AZ ERKÖLCSTELENNÉ VÁLÁS ZUHANÁS & \\
\hline
\end{tabular}

4. táblázat. AZ ERKÖLCS ERŐ metafora elöfordulási mutatói a magyar korpuszban

A kvalitatív és kvantitatív elemzésböl levont következtetéseket a laikus modellek bemutatása során részletezem.

\subsection{AZ ERKÖLCS ERÖ fogalmi metafora a német nyelvben}

Az előző alfejezetben, a magyar elemzés során kifejtettem, hogy az 'erkölcs' fogalom konceptualizálása során fontos szerepe van az erök összejátékának. ${ }^{6}$ A német korpuszban az ERÖDINAMIKA sajátos módon manifesztálódik a nyelvi példákban.

Az erkölcs egyrészt megjelenik az ego tulajdonságaként, amely szeretne ellenállni a külső vagy belső gonosz erőnek, és erkölcsös akar maradni. ${ }^{7}$ A német nyelvűek konceptualizációs rendszerében azonban az erkölcs egy külső erö is lehet, amely valamilyen pozitív vagy negatív változást szeretne elérni:

(13) Der Protest [...] soll die Moral im Haus stärken. ('A tiltakozásnak [...] erösíteni kell a ház erkölcsét.')

(14) [...], wenn man Moral in der Politik nicht gelten lassen will. ('[...], ha nem akarjuk, hogy az erkölcs a politikában érvényesüljön.')

(15) [...], ihre Moral gegen die deutsche Lebensart verteidigen ('[...], erkölcsét a német életstílussal szemben megvédeni)

A fenti példamondatokban AZ ERKÖLCSÖSSÉG ERÖ fogalmi metafora jelenik meg. A (13) mondatban erősíteni akarják az ego ellenálló képességét, hogy tudjon erkölcsös maradni, a (14) példában valamiféle külső gonosz erő elnyomja az erkölcsöt, és nem engedi érvényesülni, míg a (15) példa szerint a német életstílus az antagonista, amellyel szemben meg kell védeni az egót. A mondatban AZ ERKÖLCSÖSSÉG ERÖ fogalmi metaforán kívül AZ ERKÖLCS ÉRTÉK és AZ ERKÖLCS mint BIRTOKOLT TÁRGY metaforák is jelen vannak.

(16) Moral wird als [...] wichtigste gesellschaftliche Kraft gesetzt. ('Az erkölcsöt a legfontosabb társadalmi erőként határozza meg.')

(17) Überzeugten am Ende vor allem durch Moral und Kampfkraft. ('A végén elsősorban erkölcs és harci szellem által győzték meg.') 
(18) Aber ich habe alles gegen Moral von der Stange, [...] ('De nagyon is van kifogásom a szögröl készen leakasztott erkölcs ellen, [...]')

A (16), (17)-es példamondatban viszont az erkölcsöt egy külső pozitív entitásként konceptualizáljuk, amelynek pozitív hatása van a társadalmi vagy egyéni fejlődésre. Az erkölcs tehát külső meggyőző erőként konceptualizálódik, amelynek köszönhetően pozitív hatás éri az agonistát. A (18)-as tagmondatban viszont mások erkölcse külső gonosz eröként jelenik meg, amely támadja az egót. A megnyilatkozónak tehát problémája van minden olyan erkölccsel, amely mint afféle konfekcionált áru/igénytelen tömegtermék jelenik meg. Ha a tömeg, a többség által elfogadott, igénytelen erkölcs csábításának engedünk, akkor erkölcstelenné válunk a saját értékrendünk alapján.

(19) [...] weder durch Gesetz, noch Moral, davon abhalten, [...] ('[...] sem a törvény, sem az erkölcs nem tartja vissza attól, hogy [...]')

A (19)-es példában visszatartó erőként a törvény formájában a külső, míg az erkölcs képében a belső erő is realizálódik. A mondatban az erkölcsöt tekintélyként is konceptualizálhatjuk, akinek hatalma van valakit visszatartani valamilyen cselekedettől.

AZ ERKÖLCSÖSSÉG ERŐ metaforikus következményei AZ ERKÖLCSÖS STABIL és AZ ERKÖLCSÖS EGYENES fogalmi metaforák, amelyek összefüggésben állnak egymással. Amennyiben az ego erkölcsös, van ereje, hogy harcoljon és győzedelmeskedjen a külső vagy belső gonosz erökkel szemben, akkor erkölcsileg stabil lábakon áll. Ha viszont valami/valaki meginog, elveszíti stabilitását, annak erkölcse is veszélybe kerül, és helyre kell állítani, mint ahogyan az alábbi (20) példamondatban olvashatjuk. Az ego akkor tudja megőrizni erkölcsösségét, ha az erőviszonyok kiegyenlítődnek, vagyis az ego ereje, valamint a külső/belső gonosz erö között egyensúly alakul ki ((21) példa):

(20) [...] die Moral im angeschlagenen Konzern wieder herstellen ('[...] a bizonytalan lábakon álló nagyvállalat erkölcsét helyreállítani’)

(21) Die Verwerfungen der globalisierten Wirtschaft und das Ende der nationalen Volkswirtschaft bedrohen die Balance zwischen Wirtschaft, Gesellschaft und Politik, zwischen dem Homo oeconomicus, dem zur Moral begabten Menschen und dem Republikaner in uns. ('A globalizált gazdaság elutasításai és a nemzeti népgazdaság vége fenyegetik az egyensúlyt a gazdaság, társadalom és politika között, a bennünk lévő Homo oeconomicus, az erkölcsre alkalmas ember és a republikánus között.')

AZ ERKÖLCSÖS EGYENES metafora a belső tartásra vonatkozik, amelynek kialakításához és megőrzéséhez az ego erejére van szükség. A metafora alapja az a testi tapasztalat, amely szerint fizikailag nem egyenes állapotban lenni meglehetösen kényelmetlen testtartás. Ha huzamosabb ideig görbén, meghajolva kell állni vagy ülni, fizikai fájdalmak jelentkeznek. Ebből kiindulva jutunk el az egyenes, stabil testtartás és belső tartás közötti kapcsolatra.

(22) [...] der Moral werden in den meisten Fällen die Mittel fehlen, alles zu richten, was aus dem Lot ist. ('[...] az erkölcsnek hiányoznak az eszközei, hogy helyreállítsa azt, ami nincs rendben.')

A (22) példában az erkölcsöt emberként konceptualizáljuk, aki képes helyreállítani azt, ami tönkrement. AZ ERKÖLCSÖS EGYENES metafora szerepe akkor válik világossá, ha tudjuk, hogy a Lot szó eredeti jelentése 'függőben lévő/abszolút függőleges, egyenes'. Tehát ami nincs rendben, az elmozdult a függöleges helyzetböl. 
A metaforikus nyelvi példák között további, erővel kapcsolatos fogalmi metaforákat azonosítottam:

\section{AZ ERKÖLCSÖS ERÖS}

(23) [...] die Moral des spanischen Volkes stärken. ('[...] a spanyol nép erkölcsét erösíteni.') (24) Da wird eine starke Moral [... ]geboten ('Ott erős erkölcsöt kínálnak [...]').

\section{AZ ERKÖLCSTELEN GYENGE}

(25) Seine Moral ist ängstlicher. ('Erkölcse félénkebb.')

(26) [...] in Kondition und Moral Schwächen zeigt. ('[...] kondícióban és erkölcsben gyengeséget tanúsít.')

(27) [...] trägt er [...] einen Zug von Feigheit, der auch seine Moral fraglich erscheinen lässt. ('[...] ha valaki [...] a gyávaság jelét mutatja, annak erkölcse is megkérdőjelezhető.')

A (27) példában a gyávaság belső gonosz erő, amely támadja az egót, gyengévé teszi azt. Ha az ego gyenge, kevésbé tud ellenállni, tehát megvan az esélye, hogy a gyávaság győz, ezáltal az ego erkölcstelenné válik.

\section{AZ ERKÖLCSTELELENNÉ VÁLÁS SZAKÍTÁS}

(28) [...] brechen mit Moral. ('[...] szakít az erkölccsel.')

Az ego és az erkölcs között kötelék van, amelyet a szakító erő segítségével meg lehet szüntetni.

Az ERŐDINAMIKA szemléltetésére egyik legjobb példa a magyar elemzés során felvázolt HARC IKM, amelynek alábbi elemei manifesztálódnak a német nyelvü korpuszban:

ERKÖLCSÖSNEK MARADNI HARCOLNI

(29) [...] Kampf um Anstand und Moral [...] ('[...] küzdelem az illemért és erkölcsért [...])

ERKÖLCSÖSNEK MARADNI GYÖZNI

(30) Ein Sieg der Moral, wie Copado sagt. ('Az erkölcs győzelme, ahogy Copado mondja.')

(31) Die Moral muss siegen, wenn unsere Jungs mit dem Taschengeld auf die Millionäre treffen. ('Az erkölcsnek győznie kell, ha fiaink a zsebpénzükkel váratlanul találkoznak a milliomosokkal.')

\section{AZ ERKÖLCSTELENNÉ VÁLÁS BUKÁS/VERESÉG}

(32) Die Stadt ist ein Ort der unübersichtlich gewordenen Angebote an ästhetischen und materiellen Reizen, der Ideen und Ideologien, in der die traditionelle Moral nur noch ein Schattendasein führt. ('A város az a hely, ahol az esztétikai és materiális csábítás, az ötletek és ideológiák kínálata áttekinthetetlen, amelyben a hagyományos erkölcs már csak árnyékként létezik.')

A (32) példamondatban a vágyak és az erkölcs állnak szemben egymással. A mondat második feléből kiderül, hogy a küzdelemben a csábítás győzött, hiszen az erkölcs visszaszorult, és már csak árnyékként van jelen a városban. 


\begin{tabular}{|l|l|}
\hline AZ ERKÖLCS ERÖ & Gyakoriság $(\%)$ \\
\hline Szerkezeti metafora & 36,99 \\
\hline A JÓ CSELEKEDET FENT VAN & 26,71 \\
\hline AZ ERKÖLCSÖSSÉG ERŐ & 9,59 \\
\hline ERKÖLCSÖSNEK MARADNI GYÖZNI A HARCBAN & 8,22 \\
\hline A ROSSZ CSELEKEDET LENT VAN & 6,85 \\
\hline ERKÖLCSTELENNÉ VÁLNI VESZÍTENI A HARCBAN & 6,85 \\
\hline JÓNAK (ERKÖLCSÖSNEK) LENNI EGYENSÚLYBAN LENNI & 3,42 \\
\hline AZ ERKÖLCSTELENNÉ VÁLÁS SÜLLYEDÉS & 1,37 \\
\hline A KÍSÉRTÉS ERÖ & \\
\hline
\end{tabular}

4. táblázat. AZ ERKÖLCS ERÖ metafora elöfordulási mutatói a magyar korpuszban

A gyakorisági mutatók alapján AZ ERKÖLCS ERŐ metafora leggyakoribb szerkezeti metaforái a JÓ CSELEKEDET FENT VAN éS AZ ERKÖLCSÖSSÉG ERÖ. A HARC IKM elemei hasonló előfordulási arányt mutatnak.

\subsection{Laikus modellek}

Egy elvont fogalom laikus modellje azokból a tudásfragmentumokból épül fel, amelyeket egy kultúr- vagy nyelvközösség tagjai mindennapi életük során gyüjtenek össze. Ezek főleg hétköznapi megfigyelések a körülöttünk lévő világ müködéséről. Az így szerzett tapasztalatok alkotják fogalmi rendszerünk alapját, amelyek révén elvont fogalmainkat konceptualizáljuk.

Az 'erkölcs' a korpuszban az 'ego' és 'kísértés' dinamikájában realizálódik. Ennek megfelelően állítható fel az azonosított fogalmi metaforák által az a dinamikus laikus modell, amelyben AZ ERKÖLCSÖSSÉG ERŐ metafora a domináns.

\subsubsection{A magyar laikus modell}

A modell alapján az erkölcsösség az érzelmekhez hasonlóan egy állapot, amely valamilyen ráhatás miatt megváltozhat. A modell a 3. alfejezetben felvázolt ERŐDINAMIKÁra épül.

A modell részei tehát:

- erkölcsös állapot;

- erkölcstelen állapot;

- a változás oka: egy külső vagy belső erő.

Az erkölcs az erőviszonyok dinamikájában, összjátékában jelenik meg.

A modell szerinti értelmezési folyamatban az ESEMÉNYSTRUKTÚRA metaforarendszer vesz részt, amely szerint:

- AZ ÁLLAPOTOK TÉRBEN LÉVÖ ZÁRT TERÜLETEK/HELYEK (Egy cigánytelepen született. Egy szegény hatgyermekes családban, becsületben és < erkölcsben >.)

- AZ ÁLlAPOTVÁLTOZÁS MOZGÁS ([...] mivel < erkölcs >, szabályok, irányitás nélkül a globalizáció útja nem jó felé halad)

- A VÁLTOZÁS OKA ERŐ (A reneszánsz lesújtó hatással volt Európa-szerte az Egyházra, különösen a föpapok < erkölcseire >.) 
- A CSELEKVÉS ÖNERŐBÖL VÉGZETT MOZGÁS ( Az új évezred kihívásainak az ország csak akkor tud megfelelni, ha az (elit)értelmiségiek nem egymás agyontiprásán, hanem - józan ésszel és tiszta < erkölccsel > - az ország elörelépése érdekében fáradoznak.)

- A NEHÉZSÉGEK AKADÁLYOK (Úgy érzi, az < erkölcs > akadályozná az ő cselekvési szabadságát.)

Az erkölcs fogalomra kivetítve a fenti felsorolás azt jelenti, hogy az erkölcs az ego ereje, amellyel leküzdhetjük a külső vagy belső gonosz erőket. Ha az ego győzedelmeskedik, akkor nem történik változás, tehát az ember erkölcsös állapotában marad. Ellenkező esetben a gonosz erő felülkerekedik az egón, az elveszíti a kontrollt és az ember erkölcstelenné válik. Az erkölcstelenné válást esésként konceptualizáljuk A JÓ FENT VAN és A ROSSZ LENT VAN fogalmi metaforák által.

A magyar példák alapján az erkölcsnek korlátozó szerepe van az emberek életében. Ha AZ ÉLET UTAZÁS metaforát hívjuk segítségül, akkor eljutunk AZ ERKÖLCSÖS ÉLET KORLÁTOZOTT UTAZÁS/MOZGÁs fogalmi metaforához. A MORÁLIS KORLÁT megjelenik AKADÁLYKÉNT, illetve a mozgástér HATÁRaként is. Tehát az erkölcs megakadályoz minket abban, hogy erkölcstelen dolgot cselekedjünk, valamint határt szab. Az utazás során az erkölcs lehet az IRÁNYMUTATÓnk is, amelyet követünk.

\subsubsection{A német laikus modell}

Az 'erkölcs' laikus modelljét a magyarhoz hasonlóan az elemzés eredményei alapján építem fel. A fogalmi metaforák utalnak ugyanis arra, hogy a német nyelvközösség tagjai milyen tudással rendelkeznek a fogalomról, és a mindennapi életük során összegyűjtött tapasztalataikat hogyan hasznosítják.

Az 'erkölcs' a német nyelvü példákban is az 'ego' és 'kísértés' dinamikájában realizálódó erő. A modell dinamikussága abban rejlik, hogy a külső és belső erők közötti állandó harc révén változhat az egyén erkölcsössége az ERÖDINAMIKA sémának megfelelően. Az erkölcsösség változása valójában az egyén állapotának változása, amelyet a már említett ESEMÉNYSTRUKTÚRA komplex metafora révén helyváltozásként konceptualizálunk. Az állapotváltozás oka egy külső vagy belső erőhatás.

A német nyelvü kifejezésekben AZ ERKÖLCSÖSSÉG ERŐ metafora kétféleképpen jelenik meg: AZ ERKÖLCS AZ EGO EREJE, AZ ERKÖLCS KÜLSÖ ERÖ.

Az erkölcsös ember egója erős, tehát képes legyőzni az őt érő külső vagy belső gonosz erőt, ezáltal állapota nem változik meg. Ha az ego gyenge, akkor nem képes ellenállni, vagyis állapotváltozás történik az erő hatására, ennek eredményeképp az egyén erkölcstelenné válik.

AZ ERKÖLCS KÜLSÖ ERÖként kifejthet pozitív és negatív hatást egyaránt. Az emberek közötti interakció a német nyelvü példákban ebben a keretben is manifesztálódik. Mások erkölcse hatással van ránk, és ennek következtében változik meg az állapotunk jó vagy rossz irányba.

Az állapotváltozást a német nyelvüek süllyedésként konceptualizálják A JÓ FENT VAN és A ROSSZ LENT VAN fogalmi metaforák közvetítésével.

A német példák alapján az erkölcsöt leggyakrabban iránymutatóként konceptualizáljuk. Megjelenik a korlátozó szerep is a MORÁLIS KORLÁT metaforában. Az egyenes úton történő mozgás viszont nem manifesztálódik a nyelvi példákban. 


\section{6 Összefoglalás}

A dinamikus modellek legfontosabb különbözősége abban rejlik, hogy a középpontban lévő AZ ERKÖLCSÖSSÉG ERŐ metafora a német nyelvben külső és belső erő is lehet. Míg a magyarban AZ ERKÖLCS AZ EGO BELSŐ EREJE, a németben emellett AZ ERKÖLCS KÜLSÖ ERÖ metafora is részt vesz a konceptualizációs folyamatban. Külső eröként mások egóját támadja, ez esetben „erkölcsök harcáról” beszélhetünk.

Az ego állandó harcot vív a külső és belső gonosz erőkkel, amelyek támadják. Ha az ego elég erős és ellenáll, akkor nem történik változás, tehát az ember erkölcsös marad. Ellenkező esetben a gonosz erő felülkerekedik az egón, az elveszíti a kontrollt, és az ember erkölcstelenné válik. Az erkölcstelenné válást a magyar nyelvben esésként, míg a német nyelvben inkább süllyedésként konceptualizáljuk A JÓ FENT VAN és A ROSSZ LENT VAN fogalmi metaforák által.

A hasonlóságok dominanciáját a generikus szintü erkölcsmodellekben azzal magyarázhatjuk, hogy két közép-európai nemzetről és/vagy nyelvközösségröl beszélünk, amelyek sorsa, kultúrája, történelme az előző évszázadok, évtizedek alatt összefonódott, nyelvük állandó kölcsönhatásban volt. Kevésbé beszélhetünk tehát kulturális-ideológiai különbségekröl, mint pl. nyugati és keleti kultúrák összehasonlítása esetén.

Az elemzés során fény derült arra, hogy az ERÖDINAMIKA jelentős mértékben hozzájárul az erkölcsfogalom konceptualizációjához. Számos nyelvi példa bizonyítja, hogy a magyar és német nyelvü beszélők az értelmezési folyamat során az erő mint fizikai jelenség egyes tulajdonságait kivetítik az átvitt értelembe vett harcra, miközben próbálnak erkölcsösek maradni. A kutatás során beigazolódott, hogy a Lakoff (1996) és Lakoff \& Johnson (1999) által intuitív nyelvi példák alapján felépített erkölcskoncepció valóban manifesztálódik mind a magyar, mind a német nyelvü élőbeszédben is.

A jelen tanulmányban használt ,alulról felelé” építkező vizsgálati módszer alkalmasnak bizonyult arra, hogy a magyar és német nyelvközösség esetében rávilágítsunk az ERÖDINAMIKA képi séma nyelvi manifesztációjára, AZ ERKÖLCS ERŐ metafora elemeire, és metaforikus nyelvi kifejezések elemzéséből levonható következtetésekből felépítsük a laikus modelleket. Ezáltal a tanulmány elérte a kutatás kezdetén megfogalmazott célkitüzést.

\section{Irodalom}

Alverson, H. (1994): Semantics and experience. Universal metaphors of time in English, Mandarin, Hindi, and Sesotho. Baltimore: Johns Hopkins University Press. https://doi.org/10.2307/415900

Banćzerowski, J. (1999): A kognitív nyelvészet alapelvei. Magyar Nyelvőr 123(1), 78-87.

Banćzerowski, J. (2000): A nyelv és a nyelvi kommunikáció alapkérdései. Budapest: ELTE, BTK.

Clausner, T.C. \& Croft, W. (1997): Productivity and schematicity in metaphors. Cognitive Science 21(3), 247-82. https://doi.org/10.1207/s15516709 $\operatorname{cog} 2103 \_1$

Dobrovolskij, D. \& Piirainen, E. (2005): Figurative language: Cross-cultural and crosslinguistic perspective. Amsterdam: Elsevier.

Ekman, P., Levenson, R.W. \& Friesen, W.V. (1983): Autonomic nervous system activity distinguishes among emotions. Science 221, 1208-1210.

https://doi.org/10.1126/science.6612338 
Flanagan, O. (1992): Consciousness reconsidered. Cambridge: MIT Press. https://doi.org/10.2307/2185744

Johnson, M. (1991): Knowing through the body. Philosophical Psychology 4(1), 3-18. https://doi.org/10.1080/09515089108573009

Kövecses, Z. (2005a): A metafora. Gyakorlati bevezetés a kognitív metaforaelméletbe. Budapest: Typotex.

Kövecses, Z. (2005b): Metaphor in culture: universality and variation. Cambridge/New York: Cambridge University Press. https://doi.org/10.1017/CBO9780511614408

Kövecses, Z. (2006a): A fogalmi metaforák elmélete és az elmélet kritikája. Világosság 8-9-10, 87-97.

Kövecses, Z. (2006b): Language, mind and culture. New York: Oxford University Press.

Kövecses, Z. (2010a): Metaphor: A practical introduction. Second edition. New York: Oxford University Press.

Kövecses, Z. (2010b): Metaphor, language, and culture. D.E.L.T.A. 26, 739-757. https://doi.org/10.1590/S0102-44502010000300017

Kövecses, Z. (2012): Creating metaphor in context. In: Kleinke, S., Kövecses, Z., Musolff, A. \& Szelid, V. (eds.): Cognition and culture. Budapest: ELTE Eötvös Kiadó, 28-43. https://doi.org/10.1075/ijolc.1.1.02kov

Kövecses, Z. (2015): Where metaphors come from: Reconsidering context in metaphor. New York: Oxford University Press. https://doi.org/10.1080/10926488.2015.1074808

Kövecses, Z. \& Benczes, R. (2010): Kognitív nyelvészet. Budapest: Akadémiai Kiadó. https://doi.org/10.1556/9789630597340

Kövecses, Z., Szelid, V., Nucz, E., Blanco-Carrion, O., Akkök, E.A. \& Szabó, R. (2015): Anger metaphors across languages: A cognitive linguistic perspective. In: Heredia, R. R. \& Cieślicka, A. B. (eds.): Bilingual figurative language processing. Cambridge/New York: Cambridge University Press, 341-368. https://doi.org/10.1017/CBO9781139342100.017

Lakoff, G. (1996): Moral politics. Chicago: University of Chicago Press.

Lakoff, G. (2002): Moral politics: How liberals and conservatives think. Chicago: University of Chicago Press. https://doi.org/10.7208/chicago/9780226471006.001.0001

Lakoff, G. \& Johnson, M. (1980): Metaphors we live by. Chicago: University of Chicago Press.

Lakoff, G. \& Johnson, M. (1999): Philosophy in the flesh. New York: Basic Books.

Lakoff, G. \& Turner, M. (1989) More than cool reason: A field guide to poetic metaphor. Chicago: University of Chicago Press. https://doi.org/10.2307/415109

Pfaff, K. L., Gibbs, R. W. \& Johnson, M. D. (1997): Metaphor in using and understanding euphemism and dysphemism. Applied Psycholinguistics 18(1), 59-83. https://doi.org/10.1017/S0142716400009875

Pragglejaz Group (2007): MIP: A method for identifying metaphorically used words in discourse. Metaphor and Symbol, 22(1), 1-39. https://doi.org/10.1080/10926480709336752

Rakova, M. (2002): The philosophy of embodied realism: A high price to pay? Cognitive Linguistics 13, 215-244. https://doi.org/10.1515/cogl.2002.015

Semino, E. (2005): The metaphorical construction of complex domains: The case of speech activity in English. Metaphor and Symbol 20-21, 35-70. https://doi.org/10.1207/s15327868ms2001_2

Sharifian, F. (2006): A cultural-conceptual approach and world Englishes: The case of aboriginal English. World Englishes, 25(1), 11-22.

https://doi.org/10.1111/j.0083-2919.2006.00444.x 
Sharifian, F. (2008): Distributed, emergent cultural cognition, conceptualisation, and language. In: Frank, R. M., Dirven, R., Ziemke, T. \& Bernárdez, E. (eds.): Body, language, and mind. Volume 2: Sociocultural situatedness. Berlin/New York: Mouton de Gruyter, 109-137.

Steen, G. J. (1999): From linguistic to conceptual metaphor in five steps. In: Gibbs, R. W. \& Steen, G. J. (eds.): Metaphor in cognitive linguistics. Amsterdam: John Benjamins Publishing Company, 57-77. https://doi.org/10.1075/cilt.175.05ste

Steen, G. J., Dorst, A. G., Herrmann, J. B., Kaal, A. A., Krennmayr, T. \& Pasma, T. (2010): A method for linguistic metaphor identification. From MIP to MIPVU. Amsterdam, Philadelphia: John Benjamins Publishing Company. https://doi.org/10.1075/celcr.14

Stefanowitsch, A. (2006): Words and their metaphors: A corpus-based approach. In: Stefanowitsch, A. \& Gries, S.Th. (eds.): Corpus-based approaches to metaphor and metonymy. Berlin, New York: Mouton de Gruyter, 61-105. https://doi.org/10.1515/9783110199895.63

Szelid, V. (2007): Szerelem és erkölcs a moldvai csángó népdalokban: Kognitív szemantikai elemzés. PhD dolgozat. Budapest: Eötvös Loránd Tudományegyetem.

Talmy, L. (1988): Force dynamics in language and cogniton. Cognitive Science, 12, 49-100. https://doi.org/10.1207/s15516709 $\operatorname{cog} 1201 \_2$

Zinken, J. (2007): Levels of schematicity in metaphor: Basic level source concepts. www.port.ac.uk/departments/academic/psychology/research/languagecultureandmind/filet odownload

Dr. Lechner Ilona

II. Rákóczi Ferenc Kárpátaljai Magyar Főiskola

Filológia Tanszék, Angol Tanszéki Csoport

90202 Beregszász, Kossuth Lajos tér 6.

lechner.ilona@kmf.org.ua 